\title{
Evaluation of sanitary and veterinary inspection results of slaughtered sheep in
} Poland in 2017-2019

\author{
Krzysztof Górski*, Roman Niedziótka and Elżbieta Horoszewicz
}

\begin{abstract}
The aim of this study was to follow and evaluate the sanitary and veterinary inspection results of slaughtered sheep in Poland in the period 2017-2019. More than 175,000 sheep were slaughtered in Poland during this period. Post-mortem veterinary inspection revealed symptoms and/or lesions in 19,799 animals, which constituted $11.30 \%$ of all examined sheep. Of these, 134 animals (0.08\%) were considered unfit for consumption. The most numerous cases were with foci of pus, contamination and congestion (5.07\%) and
\end{abstract}

fasciolosis $(4.72 \%)$. The highest number of foci of pus, contamination and congestion in sheep carcasses were found in the Małopolskie and Podlaskie voivodeships. Most of the cases deemed unfit for consumption were found in the Podkarpackie (30), Swiętokrzyskie (29) and Podlaskie (23) voivodeships, accounting for over $61 \%$ of all disqualified sheep carcasses in 2017-2019 in Poland.

Key words: sheep; sanitary and veterinary examination; lesions; quality deviations

\section{Introduction}

The sheep population in Poland has remained almost unchanged over the last 15 years, at 265,500 animals. This lowers the production of sheep's milk. In 2019, livestock production was was only at 2.6 thousand tons (GUS, 2019). It is worth noting that significant achievements have been made in breeding this species, as almost 5 million sheep were kept in Poland in 1986 (Lis and Górski, 2012). Sheep production

is characterised by a low level of costs, since sheep consume cheap fodder from grasslands not available for other animal species. Natural and economic conditions can play a complementary role to animal production on small farms. In recent years, the greatest decline in the sheep population was observed in the Mazowieckie, Łódzkie and Wielkopolskie voivodeships, and currently, most sheep are kept in the Małopolskie, Podlaskie and

Krzysztof GÓRSKI*, PhD, Associate Professor, (Corresponding author, e-mail: krzysztof.gorski@uph.edu. pl), Roman NIEDZIÓŁKA, PhD, Associate Professor, Elżbieta HOROSZEWICZ, PhD, Assistant Professor, Faculty of Agrobioengineering and Animal Sciences, Institute of Animal Science and Fisheries, Siedlce University of Natural Sciences and Humanities, Poland 
Wielkopolskie voivodeships (GUS, 2019). The annual per capita consumption of lamb meat in Poland is below $1 \mathrm{~kg}$ (about $40 \mathrm{~g}$ ). The average annual consumption of sheep meat per capita in EU countries in 2016 was $1.9 \mathrm{~kg}$ (Niżnikowski et al., 2017).

Changes or signs of disease found before and after the slaughter of animals provide information on the condition of animal health, which determines the nutritional suitability of the slaughter material (Nielsen, 2011). Therefore, research in this regard should be carried out systematically. The testing of slaughter animals and meat is a tool to reduce or even rule out risks to consumer safety and health. Problems arise with infections of animals that do not generate recognisable clinical signs during rearing or fattening (Blamire et al., 1980). A number of reports on the evaluation of slaughter animals in Poland has been published in recent years. The results of these studies show a significant number of slaughtered animals, especially cattle and pigs, with symptoms or lesions (Górski, 2020).

The aim of this study was to analyse and compare the frequency of symptoms and lesions in slaughter sheep in Poland in 2017-2019. The data relating to the evaluation of results of the health and veterinary examination were taken from official Veterinary Inspection documentation from all slaughterhouses under veterinary supervision.

\section{Material and methods}

The data from the health and veterinary examination was analysed from reports drawn up by the General Veterinary Inspectorate (RRW-6). Postmortem inspection included visual inspection of carcasses and organs. Pathological lesions were identified and registered through palpation and incision of suspicious organs. An analysis of the causes of disease changes was also carried out. The assessment of the causes of lesions and unfitness for consumption included: emaciation, organoleptic changes, incomplete loss of blood, natural death, pain during slaughtering, echinococcosis, fasciolosis and other parasites, foci of pus, contamination and congestion, and other causes. The analysis of results took into account the number of animals tested, the number of carcasses with lesions and the number of carcasses declared unfit for consumption. The collected specimens were compiled according to the frequency of pathological changes found in the sanitary and veterinary examination of sheep in voivodeships in Poland, and then their percentage structure was determined. Changes in the incidence of pathological conditions and lesions of slaughter sheep were analysed for the years 2017-2019. Data for 2017 were taken from earlier studies (Górski and Kondracki, 2019). No animals were slaughtered for this study, and retrospective data were used for this study.

Table 1. Results of ante-mortem and post-mortem examination of sheep in Poland in 2017-2019

\begin{tabular}{|c|c|c|c|}
\hline Year & $\begin{array}{c}\text { Number of } \\
\text { examined animals }\end{array}$ & $\begin{array}{c}\text { Number and percentage } \\
\text { of animals with lesions or } \\
\text { pathological symptoms }\end{array}$ & $\begin{array}{c}\text { Number and percentage } \\
\text { of carcasses unfit for } \\
\text { consumption }\end{array}$ \\
\hline 2017 & 43,283 & $2,202(5.08)$ & $56(0.13)$ \\
\hline 2018 & 59,712 & $12,886(21.58)$ & $36(0.06)$ \\
\hline 2019 & 72,165 & $4,711(6.52)$ & $42(0.06)$ \\
\hline Total & 175,160 & $19,799(11.3)$ & $134(0.08)$ \\
\hline
\end{tabular}




\section{Results and Discussion}

The data enabling comparison of the frequency of lesions in sheep in Poland in 2017-2019 are presented in Table 1.

More than 175,000 sheep were slaughtered and subsequently subjected to sanitary and veterinary examination during the study period. During anteand post-mortem examination, lesions or quality-related deviations were found in almost 19,800 carcasses $(11.3 \%)$. The number of animals examined during these three years varied from 43,283 sheep in 2017 to 72,165 sheep in 2019. The percentage of carcasses with lesions in the total number of slaughtered animals was highest $(21.58 \%)$ in 2018. The number of carcasses with lesions ranged from 2202 (2017) to 4711 (2019).
In total, 134 carcasses were declared unfit for consumption, or $0.08 \%$ of all animals subjected to post-mortem inspection. The percentage of carcasses declared unfit ranged from $0.005 \%$ in 2019 to $0.13 \%$ in 2017. For the sake of comparison, more than 23,500 sheep were slaughtered in 2009, and the number of animals with lesions or disease symptoms in that year was 8578 (36.35\%; Lis and Górski, 2018). Such a large number of animals with lesions may be indicative of inappropriate keeping conditions and animal welfare.

Table 2 shows the frequency of lesions in slaughtered sheep between 2017 and 2019 by type of lesion.

These data show that the sanitary and veterinary examination of sheep most often found emaciation, icterus,

Table 2. Results of post-mortem examination of sheep in Poland - types of lesions or diseases found in 2017-2019

\begin{tabular}{|c|c|c|c|c|}
\hline \multirow[t]{2}{*}{ Type of lesions } & \multicolumn{4}{|c|}{$\begin{array}{c}\text { Number and percentage of animals with lesions or pathological } \\
\text { symptoms in relation to the number of examined animals }\end{array}$} \\
\hline & 2017 & 2018 & 2019 & 2017-2019 \\
\hline Icterus & $9(0.02)$ & $4(0.01)$ & $2(0.00)$ & $15(0.01)$ \\
\hline $\begin{array}{l}\text { Septicaemia and } \\
\text { pyaemia }\end{array}$ & $9(0.02)$ & $6(0.01)$ & $6(0.01)$ & $21(0.01)$ \\
\hline Emaciation & $7(0.02)$ & $1(0.00)$ & $12(0.02)$ & $20(0.01)$ \\
\hline $\begin{array}{l}\text { Organoleptic } \\
\text { changes }\end{array}$ & $1(0)$ & $11(0.02)$ & $7(0.01)$ & 19 (0.01) \\
\hline $\begin{array}{l}\text { Incomplete loss of } \\
\text { blood, natural death, } \\
\text { pain during slaughter }\end{array}$ & 23 (0.05) & $7(0.01)$ & $0(0.00)$ & $30(0.02)$ \\
\hline Echinococcosis & $154(0.36)$ & $0(0.00)$ & $692(0.96)$ & $846(0.48)$ \\
\hline Cysticercosis & $0(0)$ & 736 (1.23) & $0(0.00)$ & $736(0.42)$ \\
\hline Fasciolosis & 1117 (2.58) & $4346(7.28)$ & 2795 (3.87) & 8258 (4.72) \\
\hline $\begin{array}{l}\text { Foci of pus, } \\
\text { contaminations and } \\
\text { congestions }\end{array}$ & 237 (2.86) & 7542 (12.63) & 1105 (1.53) & 8884 (5.07) \\
\hline Other parasites & $0(0)$ & 139 (0.23) & $0(0.00)$ & $139(0.079)$ \\
\hline Other changes & $645(1.49)$ & $94(0.15)$ & $92(0.13)$ & $825(0.471)$ \\
\hline Total & 2,202 (5.09) & 12,886 (21.58) & 4,711 (6.53) & 19,799 (11.30) \\
\hline
\end{tabular}


septicaemia and pyaemia, organoleptic changes, incomplete loss of blood, natural death, pain during slaughter, echinococcosis, fasciolosis, cysticercosis and other parasites, foci of pus, contamination and congestion, and other changes.

Table 2 shows that during the study period, the most common lesions in sheep were foci of pus, contamination and congestion $(5.07 \%)$ and fasciolosis $(4.72 \%)$, and the incidence was highest in 2018, with 7542 carcasses (12.63\%) and 4346 carcasses $(7.28 \%)$, respectively. Echinococcosis $(0.48 \%)$, cysticercosis $(0.42 \%)$ and other parasites $(0.08 \%)$ followed. The percentage of animals with incomplete loss of blood, natural death, and pain during slaughter was $0.017 \%$. Septicaemia and pyaemia were found in 21 carcasses in the analysed period, accounting for $0.012 \%$ of the examined animals. Emaciation was present in 20 carcasses $(0.01 \%$ of the examined animals). Less frequent findings were organoleptic changes (19 carcasses) and icterus (15 carcasses). Other changes were found in 825 carcasses $(0.47 \%$ of the examined animals).

Fasciolosis contagion is prevalent on a large scale in Polish sheep during the second half of July (Lis and Górski, 2012). This is due to the massive presence of slugs and the period of larval development of the fluke to the invasive stage. The main source of the invasion is wet or periodically damp pastures. The source of the invasion may also be damp fresh hay harvested from meadows where sheep infected with the fluke grazed (John et al., 2019). A factor conducive to the spread of the fluke in Poland are the many deer, particularly roe deer, one of the main hosts of Fasciola hepatica (Kornaś et al., 2005; Górski and Kondracki, 2020). A severe invasion of the liver fluke causes significant economic losses. Among the causes and effects of direct and indirect economic losses resulting from fasciolosis, it is assumed that about $70 \%$ of these losses result directly from pathological changes, and the remaining $30 \%$ are indirect consequences of the parasite's activity. The losses seen by the breeder are only $30 \%$ of the damage caused by the liver fluke. Economic losses include: reduced production of meat and wool, declined fertility rate, and expenditures for anthelmintics (Carnevale et al., 2013; Efrem et al., 2015; Ahmad et al., 2017). Fasciola spp. is found in many parts of the world (Mas-Coma, 2004). In a study conducted in Iran, $8.57 \%$ of sheep livers were infected by F. hepatica (Ghazani et al., 2008). The prevalence of liver contamination due to F. hepatica in Brazil corresponded to $8.87 \%$ (Da Cunha et al., 2007). Elsewhere in Africa, Fasciola spp. were found in $10.8 \%$ of slaughtered sheep in Algeria (Mekroud et al., 2004). Infection rate of fasciolosis in sheep and goats in Pakistan, Turkey, Nigeria and Saudi Arabia was reported at 51.3\% and $14.8 \%, 3.99 \%, 9-10.3 \%, 0.04 \%$ and $0.00 \%$, respectively (Theodoropoulos, 2011; Liba et al., 2017). F. hepatica is widespread in Europe, though with an uneven spatial distribution and strong regional variations in prevalence. Countryspecific surveys show herd-level prevalence ranging from $4 \%$ in Italy to $61.6 \%$ in Ireland in sheep farms (Rinaldi et al., 2015).

The frequency of conditions and lesions of slaughter sheep in Poland shows territorial differences. The data enabling the analysis of the occurrence of the most important conditions and lesions of sheep in particular regions of Poland is presented in Tables 3 and 4. The most frequent lesions of slaughtered sheep in Poland are foci of pus and congestion, found in 12 voivodeships. The highest number of foci of pus, congestions and contaminations in sheep carcasses was recorded in the Małopolskie (6427) and Podlaskie (4077) voivodeships (Table 3). A total of 10,504 cases of foci of pus, 
congestion and contamination were found in the Małopolskie and Podlaskie voivodeships, or $81 \%$ of all cases of these lesions found in Poland during the study period.

In 2017-2019, the extent of liver fluke invasion in sheep ranged from $0.30 \%$
(Dolnośląskie) to $14.79 \%$ (Łódzkie) (Table 4).

In 2017-2019, 134 carcasses, or $0.08 \%$ of all examined carcasses were declared unfit for consumption (Table 5). The highest number of sheep carcasses declared unfit for consumption was found

Table 3. Prevalence of foci of pus, contamination and congestion in sheep by voivodeships

\begin{tabular}{|l|c|c|c|c|}
\hline \multirow{2}{*}{ Voivodeship } & \multicolumn{4}{|c}{$\begin{array}{c}\text { Number and percentage of animals with foci of pus, } \\
\text { contamination and congestion in relation to the number of } \\
\text { examined animals }\end{array}$} \\
\cline { 2 - 5 } & 2017 & 2018 & 2019 & $2017-2019$ \\
\hline Dolnośląskie & $0(0)$ & $4(0.21)$ & $0(0)$ & $4(0.08)$ \\
\hline Kujawsko-pomorskie & $0(0)$ & $5(6.94)$ & $0(0)$ & $5(2.33)$ \\
\hline Łódzkie & $0(0)$ & $34(6.73)$ & $19(1.68)$ & $53(2.22)$ \\
\hline Mazowieckie & $50(0.60)$ & $302(2.20)$ & $455(2.24)$ & $807(1.91)$ \\
\hline Małopolskie & $162(1.89)$ & $6044(38.76)$ & $221(1.22)$ & $6427(15.15)$ \\
\hline Podkarpackie & $20(0.13)$ & $19(0.10)$ & $18(0.09)$ & $57(0.11)$ \\
\hline Podlaskie & $3460(1.72)$ & $604(31.41)$ & $13(0.91)$ & $4077(75.91)$ \\
\hline Pomorskie & $0(0)$ & $2(0.21)$ & $3(0.15)$ & $5(0.11)$ \\
\hline Śląskie & $61(4.58)$ & $127(10.85)$ & $23(1.86)$ & $211(5.65)$ \\
\hline Świẹtokrzyskie & $594(23.66)$ & $368(15.12)$ & $0(0)$ & $962(12.07)$ \\
\hline Warmińsko-mazurskie & $0(0)$ & $0(0)$ & $349(24.95$ & $349(12.11)$ \\
\hline Wielkopolskie & $4(0.42)$ & $33(3.53)$ & $4(0.30)$ & $41(1.26)$ \\
\hline
\end{tabular}

Table 4. Voivodeships where fasciolosis was found in sheep between 2017-2019

\begin{tabular}{|l|c|c|c|c|}
\hline \multirow{2}{*}{ Voivodeship } & \multicolumn{4}{|c|}{$\begin{array}{c}\text { Number and percentage of animals with fasciolosis in relation } \\
\text { to the number of examined animals }\end{array}$} \\
\cline { 2 - 5 } & 2017 & 2018 & 2019 & $2017-2019$ \\
\hline Dolnośląskie & $0(0)$ & $16(0.84)$ & $0(0)$ & $16(0.30)$ \\
\hline Łódzkie & $0(0)$ & $353(69.90)$ & $0(0)$ & $353(14.79)$ \\
\hline Mazowieckie & $40(0.48)$ & $30(0.22)$ & $1991(9.82)$ & $2061(4.87)$ \\
\hline Małopolskie & $306(3.49)$ & $0(0)$ & $32(0.18)$ & $338(0.80)$ \\
\hline Podkarpackie & $710(4.69)$ & $1507(8.09)$ & $711(3.55)$ & $2928(5.44)$ \\
\hline Podlaskie & $0(0)$ & $64(3.33)$ & $3(0.21)$ & $67(1.25)$ \\
\hline Śląskie & $19(1.42)$ & $19(1.62)$ & $29(2.35)$ & $67(1.79)$ \\
\hline Świętokrzyskie & $15(0.60)$ & $17(0.70)$ & $15(0.50)$ & $47(0.59)$ \\
\hline Wielkopolskie & $27(2.82)$ & $62(6.64)$ & $14(1.04)$ & $103(3.17)$ \\
\hline
\end{tabular}


Table 5. Number and percentage of carcasses declared unfit for consumption by voivodeship in 20172019.

\begin{tabular}{|l|c|c|c|c|}
\hline \multirow{2}{*}{ Voivodeship } & \multicolumn{4}{|c|}{$\begin{array}{c}\text { Number and percentage of carcasses declared unfit for } \\
\text { consumption in relation to the number of examined animals }\end{array}$} \\
\cline { 2 - 5 } & 2017 & 2018 & 2019 & $2017-2019$ \\
\hline Dolnośląskie & $0(0)$ & $0(0)$ & $2(0.11)$ & $2(1.49)$ \\
\hline Łódzkie & $0(0)$ & $15(2.97)$ & $0(0)$ & $15(11.19)$ \\
\hline Małopolskie & $7(0.08)$ & $2(0.01)$ & $10(0.05)$ & $19(14.18)$ \\
\hline Mazowieckie & $0(0)$ & $3(0.02)$ & $0(0)$ & $3(2.24)$ \\
\hline Podkarpackie & $24(0.16)$ & $3(0.02)$ & $3(0.01)$ & $30(22.39)$ \\
\hline Podlaskie & $18(0.90)$ & $5(0.26)$ & $0(0.00)$ & $23(17.16)$ \\
\hline Pomorskie & $0(0)$ & $1(0.10)$ & $2(0.10)$ & $3(2.24)$ \\
\hline Śląskie & $1(0.08)$ & $0(0)$ & $0(0.00)$ & $1(0.75)$ \\
\hline Świętokrzyskie & $6(0.24)$ & $7(0.29)$ & $16(0.53)$ & $29(21.64)$ \\
\hline Zachodniopomorskie & $0(0)$ & $0(0)$ & $9(7.56)$ & $9(6.72)$ \\
\hline
\end{tabular}

in Podkarpackie (30), Świętokrzyskie (29) and Podlaskie (23) voivodeships, or 82 in total, accounting for $61 \%$ of all disqualified sheep carcasses.

In conclusion, it should be noted that the number of slaughtered sheep showing deviations in terms of health condition or symptoms and lesions remains relatively high in Poland. The large number of foci of pus, contamination and congestion indicates poor care for animal welfare, hygiene and slaughter conditions, and in the cutting and processing of carcasses. Parasitic diseases, especially fasciolosis in sheep in certain regions, require more effective measures to reduce and eliminate them, due to the significant economic losses caused by strong infestations. Determining the magnitude of these losses is very difficult due to the complex biological life cycle of the parasite on the one hand and the complex pathogenic effect on the host organism on the other. It is also advisable that effective measures be implemented in the rearing and breeding of sheep and their movement to areas with pasture and environmental reserves.

\section{References}

1. AHMAD, M., M. N. KHAN, M. S. SAJID, G. MUHAMMAD, A. QUDOOS and H. M. RIZWAN (2017): Prevalence, economic analysis and chemotherapeutic control of small ruminant fasciolosis in the Sargodha district of Punjab, Pakistan. Vet. Ital. 53, 47-53.

2. BLAMIRE, R., R. GOODHAND and K. TAYLOR (1980): A review of some animals diseases encountered at meat inspections in England and Wales, 1969 to 1978 . Vet. Rec. 106, 195-199.

3. CARNEVALE, S., M. CABRERA, C. CUCHER, J. RISIO, J. MALANDRINI, L. KAMENETZKY, M. ALAZRAQUI, C. B. ETCHART, M. L. PANTANO and J. N. VELASQUEZ (2013): Direct, immunological and molecular techniques for a fasciolosis survey in a rural area of San Luis, Argentina. J. Parasit. Dis. 37, 251-259.

4. DA CUNHA, F. O. V., S. M. T. MARQUES and M. J. T. DE MATTOS (2007): Prevalence of slaughter and liver condemnation due to Fasciola hepatica among sheep in the state of Rio Grande do Sul, Brazil 2000 and 2005. Parasitol. Latinoam. 62, 188-191.

5. EFREM, L., B. SERDA, B. SIBHAT and E. HIRPA (2015): Causes of organ condemnation, its public health and financial significance in Nekemte municipal abattoir, Wollega, Western Ethiopia. J. Vet. Med. Anim. Health 7, 205-214.

6. GHAZANI, M. H. M., M. R. VALILOU, A. R. AHMADZADEH, A. R. KARAMI and K. ZIRAK (2008): The prevalence of sheep liver trematodes in the northwest region of Iran. Turk. J. Vet. Anim. Sci. 32, 305-307.

7. GÓRSKI, K. (2020): Welfare of cattle and pigs in terms of meat inspection data. In: Legal protection of animals. 
International Scientific Conference "Domestic, European Union and International Standards in Legal Protection of Animals". Maria Curie-Skłodowska University Press, Lublin, pp. 309-317.

8. GÓRSKI, K. and S. KONDRACKI (2019): Analysis and comparison of the frequency of pathological conditions and lesions in slaughtered animals in Poland in 2009 and 2017. Folia Pomer. Univ. Technol. Stetin. Agric. Aliment. Pisc. Zootech. 350, 15-24.

9. GÓRSKI, K. and S. KONDRACKI (2020): The evaluation of sanitary and veterinary inspection results of deer in Poland in 2015-2018. Folia Pomer. Univ. Technol. Stetin. Agric. Aliment. Pisc. Zootech. 354, 5-16.

10. GUS - Główny Urząd Statystyczny. Rocznik Statystyczny Leśnictwa. Warszawa 2019 [Central Statistical Office, Warsaw 2019].

11. JOHN, B. C., D. R. DAVIS, D. J. L. WILLIAMS and J. E. HODGKINSON (2019): A review of our current understanding of parasite survival in silage and stored forages, with a focus on Fasciola hepatica metacercariae. Grass Forage Sci. 74, 211-217.

12. KORNAŚ, S., B. NOWOSAD, M. SKALSKA and A. WRÓBEL (2005): Zarażenie bydła mlecznego Fasciola hepatica w gospodarstwach drobnotowarowych. Med. Weter. 61, 1368-1369.

13. LIBA, J. W., M. I. FRANCIS and N. N. ALSANDA (2017): Seasonal prevalence and comparison between sensitivity of conventional and serological detection of fasciolosis in ruminants slaughtered in Maiduguri abattoir, northeast Nigeria. Bull. Anim. Hlth. Prod. Afr. 65, 25-35.

14. LIS, H. and K. GÓRSKI (2012): Wyniki badania sanitarno-weterynaryjnego owiec rzeźnych w Polsce. Życie Wet. 87, 419.

15. LIS, H. and K. GÓRSKI (2018): Wyniki badania sanitarno-weterynaryjnego owiec rzeźnych w
Polsce [The evaluation of sanitary and veterinary inspection results of slaughter sheep in Poland]. Życie Wet. 93, 185-186.

16. MAS-COMA, S. (2004): Human fascioliasis epidemiological patterns in human endemic areas of South America, Africa and Asia. Southeast Asian J. Trop. Med. Public Health 35, 1-11.

17. MEKROUD, A., A. BENAKHLA, P. VIGNOLES, D. RONDELAND and G. DREYFUSS (2004): Preliminary studies on the prevalences of natural fasciolosis in cattle, sheep, and the host snail (Galba truncatula) in north-eastern Algeria. Parasitol. Res. 92, 502-505.

18. NIELSEN, A. (2011): Data warehouse for assessing animal health, welfare, risk management and communication. Acta Vet. Scand. 53, S3.

19. NIŻNIKOWSKI, R., T. ROKICKI, S. ŁABA and K. KRAJEWSKI (2017): Sytuacja strategiczna sektora owczarskiego w Polsce - uwarunkowania hodowlane, rynkowe i ekonomiczne [Strategic situation of the sheep-farming sector in Poland - breeding, market and economic conditions]. Przegląd Hod. 4, 1-6.

20. RINALDI, L., A. BIGGERI, V. MUSELLA, T. DE WAAL, H. HERTZBERG, F. MAVROT and D. CATELAN (2015): Sheep and Fasciola hepatica in Europe: The GLOWORM experience. Geospat. Health 9, 309.

21. RRW-6. Sprawozdania z wyników urzędowego badania zwierząt rzeźnych i mięsa za 2017, 2018 i 2019 rok [Veterinary statistical reporting]. Warszawa, Główny Inspektorat Weterynarii.

22. THEODOROPOULOS, G. (2011): Risk factors and geospatial modelling for the presence of Fasciola hepatica infection in sheep and goat farms in the Greek temperate Mediterranean environment. J. Parasitol. 138, 926-938.

\section{Procjena rezultata sanitarne i veterinarske inspekcije zaklanih ovaca u Poljskoj u razdoblju 2017.-2019. godine}

Dr. sc. Krzysztof GÓRSKI, izvanredni profesor, dr.sc. Roman NIEDZIÓŁKA, izvanredni profesor, dr. sc. Elżbieta HOROSZEWICZ, docentica, Fakultet agrobioinženjerstva i animalnih znanosti, Institut za animalnu znanost i ribarstvo Sveučilišta prirodnih i humanističkih znanosti Siedlce, Poljska

Cilj ove studije bio je pratiti i procijeniti rezultate sanitarne i veterinarske inspekcije zaklanih ovaca u Poljskoj u razdoblju 2017. 2019. godine. Više od 175000 ovaca je zaklano $\mathrm{u}$ Poljskoj u tom razdoblju. Obdukcijska veterinarska inspekcija otkrila je simptome i/ili lezije u 19799 životinja, što predstavlja $11,30 \%$ svih pregledanih ovaca. 134 zaklane životinje smatrane su neprikladnima za konzumaciju (0,08 \%). Najbrojniji su bili slučajevi s gnojnim žarištima, kontaminacijom i kongestijom (5,07 \%) i fasciolozom (4,72 \%).
Najveći broj gnojnih žarišta, kontaminacije i kongestije u lešina ovaca pronađen je u Małopolskie i Podlaskie vojvodstvima. Najviše slučajeva koji su smatrani neprikladnima za konzumaciju pronađeno je u Podkarpackie (30), Świętokrzyskie (29) i Podlaskie (23) vojvodstvima, što je predstavljalo više od $61 \%$ svih lešina ovaca proglašenih neprikladnima za konzumaciju u razdoblju 2017.-2019. godine u Poljskoj.

Ključne riječi: ovce, sanitarni $i$ veterinarski pregled, lezije, odstupanja u kvaliteti 